\title{
ALTERATION OF THE MORPHO-HYDROLOGICAL CONDITIONS OF THE AQUATIC COMPLEXES ADJACENT TO THE SF. GHEORGHE BRANCH (DANUBE DELTA) AS A RESULT OF THE HYDROTECHNICAL WORKS
}

DOI: http://dx.doi.org/10.18509/GBP.2018.46

UDC: $627.4(498: 282.243 .7 .05)$

\author{
Cristian Trifanov ${ }^{1,2}$ \\ Alin Mihu-Pintilie ${ }^{3}$ \\ Marian Mierlă ${ }^{1}$ \\ ${ }^{1}$ Danube Delta National Institute for Research and Development, Informational System and \\ Geomatics Department, 820112, Tulcea, Romania \\ 2 Alexandru Ioan Cuza University of Iași, Faculty of Geography and Geology, Department of \\ Geography, Carol I 20A, 700505, Iasi, Romania \\ ${ }^{3}$ Alexandru Ioan Cuza University of Iasi, Interdisciplinary Research Department - Field \\ Science, 54 Lascăr Catargiu St., 700107, Iasi, Romania
}

\begin{abstract}
The hydrotechnical works on Sf. Gheorghe arm in Danube Delta was done by Institute for Research and Planning for Water Management. The work was part of the framework scheme for the Dobrogea hydrographic area and was nominated in the investment plan of the National Water Council. The regularization works, started in 1988, consists in the rectification of the main meanders of the arm in the following sectors: lvancea, Dranov, Dunavăț and Murighiol. The total length of the rectification is $15 \mathrm{~km}$ and the shortening of the natural course is $32 \mathrm{~km}$. These works impose changes in the balance of the hydrological regime on the main course, along the meanders and on the channels connecting the arm waters and the aquatic complexes within the delta. By altering the fractal dimension of the arm, fluviatile processes are intensified and have irremediable long-term repercussions. This leads to the eutrophication of lakes in the aquatic complexes by low water intake, then clogging of the channels and, also, of the lakes resulting in diminishing / changing the habitats. As clear evidence are these two channels: Ivancea and Erenciuc north (completely clogged). Now, other 4 channels are threatened, which already show very low depths at the confluence with the Sf. Gheorghe arm. This is an exhaustive study of the current situation of the meanders of the Sf. Gheorghe arm from the morphological point of view and the fragile longitudinal and lateral connectivity through morphometric analysis methods using geomatics techniques. The foundation of this study will be based on existing literature, field data, historical and current data, in collaboration with other institutes and universities capable of providing important data such as sediments, hydro-technical works, etc.
\end{abstract}

Keywords: Danube Delta, wetlands, geomatics, underwater morphology

\section{INTRODUCTION}

This ongoing study represents the main author's $\mathrm{PhD}$ thesis. It is mainly a technical study that aims to enrich the hydrological data for the Sf. Gheorghe arm of the Danube Delta in respect to riverbed mapping of the meanders and their connection to the main river flow and the adjacent channels. Its results will help other research domains to benefit of the maps and database to estimate the environment development based on the actual state of 
the riverbed. The main objective of the study is to map all six meanders using high resolution hydrological equipment and to evaluate the evolution of the riverbed correlated with the historical data.

The Danube Delta is situated in the north-western sector of the Black Sea basin, in a mobile region of the terrestrial crust (the Predobrudjan Depression). Its limits are:

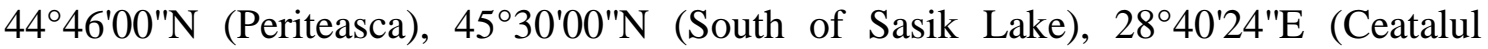
Chilia), 29 40'50"E (East of the Chilia secondary delta). As for its surface of 5,600 $\mathrm{km}^{2}$, the Danube Delta, together with the floodplain sector between Ceatalul Ismail and Galaţi City, represent the most important terminal plain of any European river (except the Volga and Kuban deltas on the territory of C.I.S.). The Ukrainian part, about one-fifth of the total Delta area, covers 125,000 ha of which 75,000 ha is land and 50,000 ha are water [1-6].

The Sf. Gheorghe arm is the oldest arm of the Danube Delta, which currently carries about $30 \%$ of the volume of water and sediments of the Danube. It derives from the Tulcea branch on the right-hand side of the bifurcation at kilometer 108.8, with mostly a single and meandering riverbed, which was naturally preserved until 1988 [7-9]. The year in which a collective effort to regulate the watercourse began so that the six meanders of the arm were subjected to a "adjustment" necessary for the protection of the shore, strongly eroded, south of the mouth of the arm and also necessary for the economic activities to the detriment of: the hydrological and sedimentological equilibrium of the adjacent aquatic complexes; the sedimentation regime at the mouths of the channels and the mouth of the arm; the reed quality; the habitats; the water surfaces; the landscape quality [1019].

Over time, the study of this aspect, namely: the impact of the redistribution of flows to the adjacent aquatic complexes following the hydrological regulations, was in depth studied immediately after the completion of the hydrotechnical works, then the studies focus on the main course of the arm, on the evolution of the sediments and the way in which it influences the mouth of the river and the evolution of the coastal area. Thus, the situation of the meanders and their silting has been left aside. The subject is of interest to the scientific environment not only for the enrichment of the poor hydrological data base on this Danube arm and for the behavioral studies of migratory fish, especially for sturgeon species, for the specificity of habitats and ecosystems that are dependent on certain physicochemical parameters of the water, impact studies and water flow improvement through hydrotechnical works. At the same time, this study responds to the requirements of national and international environmental and sustainable development policies and guidelines such as: Danube Delta Biosphere Reserve Management Plan; Water Framework Directive; European Union Strategy for Danube Region and Master Plan - Support for sustainable development in Danube Delta Biosphere Reserve

\section{STATE OF THE ART}

Regularization of Sf. Gheorghe's arm downstream from Mahmudia town was carried out on the basis of project 1274 elaborated by the Institute for Research and Development for Water Management at the command of Water Administration Office No. 1574. The work was part of the framework scheme for the Dobrogea hydrographic area and was nominated in the investment plan of the National Water Council. The regularization works consist of the rectification of the main meanders of the St. George arm in the Ivancea, Dranov, Dunavăț and Murighiol sectors. The total length of the rectification is 
$15 \mathrm{~km}$ and the shortening of the natural course of $32 \mathrm{~km}^{2}$. The project proposes to provide a clear picture of the morpho-hydrographic dynamics of the current and historical Sf. Gheorghe meanders using GIS and remote sensing methods, field data collected by single and multi-beam interferometer, ADCP and topography for a holistic understanding of how the water circulation to the aquatic complexes adjacent to the Sf. Gheorghe arm and the support capacity of its riverbed for migratory fish habitats of national and international interest.

The study of the behavior of sturgeon species migrating upstream on the Danube only on the Sf. Gheorghe arm is incipient and there are many gaps in the knowledge of this relic species. It is considered very important to identify the breeding and resting places of the individuals and this is possible only by mapping the riverbed of Sf. Gheorghe arm. According to recent studies, the sturgeons prefer to approach the deepest and largest current, and for rest they use the excavations (pits) of the riverbed with oblong shapes with a steep upstream slope beyond witch the currents are diminished or perhaps nonexistent. The identification of these excavations is necessary to know the behavior of these species, not only for a better prediction of the route in the Danube but also for the knowledge of the locations of the telemetry stations in order to monitor the captured and marked individuals. A similar problem is represented by mackerel populations. It is desirable to monitor through telemetry techniques and for this purpose it is necessary to map the riverbed of the Sf. Gheorghe arm. It is worth mentioning that these two large and main migratory fish species use only Sf. Gheorghe arm to reach the spawning located further upstream on the river.

Another problem is the morphological aspect of the arm as a result of the regularization works, namely the silting of the meanders. Besides the landscape preservation importance and the value of surface water bodies, it is the contribution of fresh and oxygenated water to adjacent aquatic complexes. Note that access (channels) to aquatic complexes lie on the edges of the meanders and the rectification directly influences the equilibrium of water distribution flows. This leads to the eutrophication of lakes in the aquatic complexes by the low intake of fresh oxygenated water, then the clogging of the lakes and the diminution of the habitats. Clear evidence is the two channels Ivancea and Erenciuc North: completely silted. At present the Perivolovca, Uzlina, Dranov and Dunavat canals are threatened, which already show very low depths at the mouth.

\section{METHODS AND TECHNIQUES}

It is proposed an exhaustive study of the current situation of the Sfântu Gheorghe meanders from the morphological point of view of and fragile longitudinal and lateral connectivity through morphometric analysis using GIS techniques and remote sensing. The foundation of this study will be based on existing literature, field data, historical and current data, in collaboration with other institutes capable of providing important data such as sediment, hydro-technical works, etc. [20-28].

Throughout the period of $\mathrm{PhD}$ studies, field data will be collected at well-established time intervals in normal and special hydrological conditions to identify the evolution and trends of the riverbed on the main course of the arm and meanders. Historical and current bathymetric data will be used that will help to correlate the erosion and silting indicators in critical areas with hydrological events. At the same time, remote sensing techniques will be used on satellite and aerial images to extract historical information on the aspect of islands and bank configuration and their correlation with hydrological events [29], 
[30]. To start with, there is a need to know how much water the Sf. Gheorghe arm takes from the Tulcea arm. Various measurements were done before by different scientists and the variations between the measurements are dependent of the water level regime and this measurement was done at the average water level quota. The flow distribution situation is very interesting now: Sulina $40 \%$ and Sf. Gheorghe $60 \%$. The bifurcation is presented in the Figure 1. and represents the starting point of the studied riverbed: St. Gheorghe.

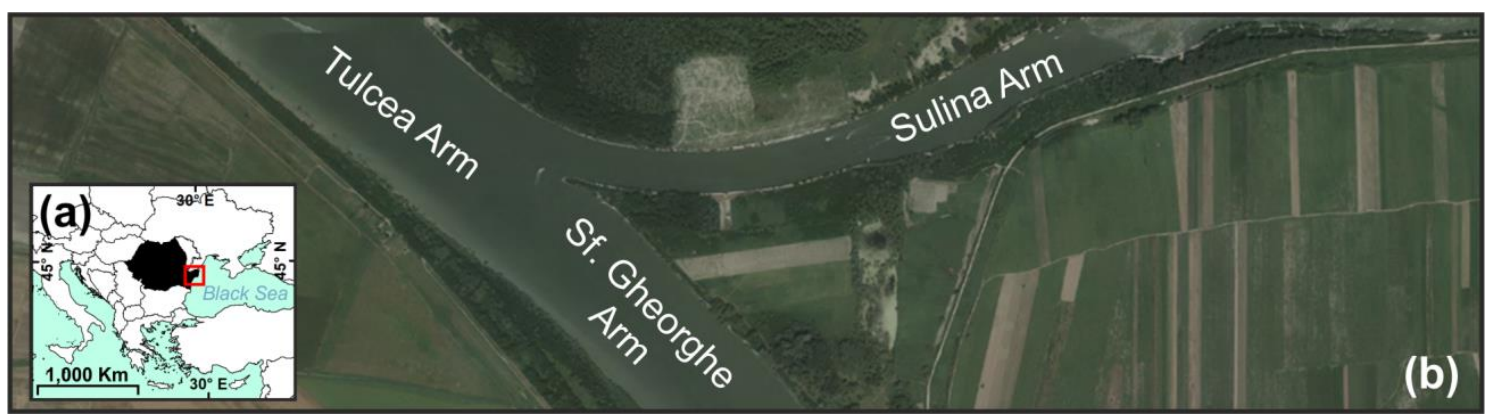

Figure 1. a. Location of the Danube Delta (SE Romania); b. The Sf. Gheorghe bifurcation

Using the flow and velocity measurement equipment at the bifurcation of the Tulcea arm in Sulina and Sf. Gheorghe, hydrometric profiles were performed and the measured flows are centralized in Table 1. The positions of these profiles and the overall distribution of the currents are represented in Figure 2.

Comparing these values to the historical values from 1992, after the hydrotechnical interventions one can notice a major change in the proportions of flow distribution on the two arms, from $63 \%$ on the Sulina arm and $37 \%$ on the Sf. Gheorghe arm to $40 \%$ on the arm Sulina and $60 \%$ on the Sf. Gheorghe branch. However, it can be noticed that the current distribution of the flows due to the hydro-morphological dynamics reached the same values as in the period 1928-1929 (41\% on the Sulina arm and 59\% on the Sf. Gheorghe branch).

Data collection started in summer 2017 and it begun at the most downstream meander on Sf. Gheorghe arm: Ivancea meander. The expedition was possible using the Danube Delta National Institute for Research infrastructure, namely ANTIPA as headquarters boat and the data collection using NAUTILUS 500, a small survey boat. The data collection process is an aggregate of different equipment for specific tasks. In order to properly map any riverbed, information such as water level quota, water velocity and discharge is critical for the final output. Beside the collection of the already mentioned data, an impetuous task is to develop the topographic support network. Since the GSM/DGPS signal is scarce throughout the whole area, determining fixed topographical points in key locations along the measured area is critical when using RTK positioning corrections of the multibeam interferometer.

The multibeam interferometer is a complex aggregate of different sensors such as: the transducer, as the emitter and the receiver of the sounding data; SVS (Sound Velocity Sensor) that applies corrections of the water sound speed, MRU (Motion Reference Unit) that applies corrections regarding the boat movement on all the three axes, Heading that applies corrections concerning the survey direction of the boat, Double frequency GPS (Global Positioning System) in RTK mode (Real Time Kinematic) for accurate positioning of the soundings and also time synchronization. 


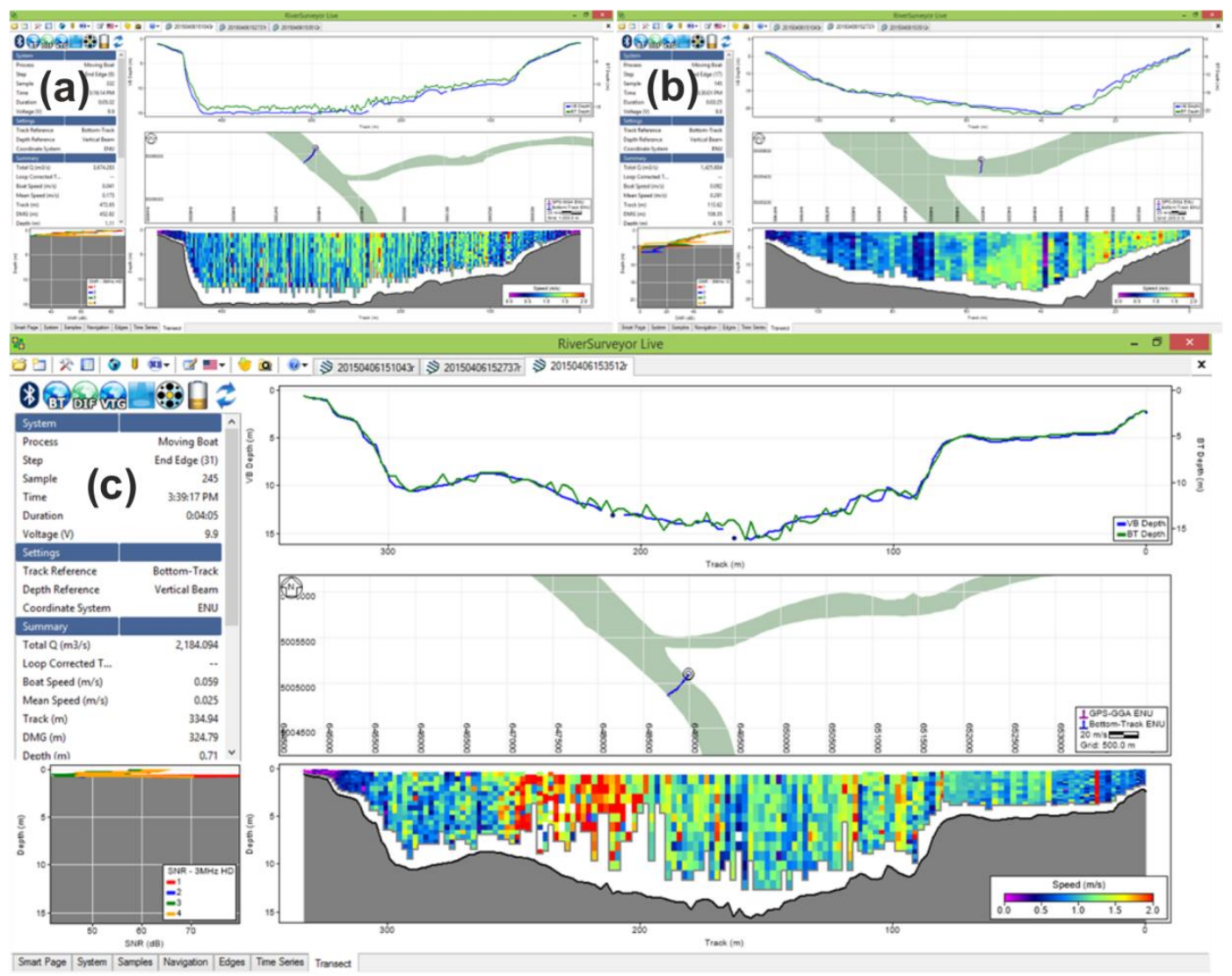

Figure 2. Hydrometrical profiles at the Sf. Gheorghe bifurcation:

a. Tulcea Arm; b. Sulina Arm; c. Sf. Gheorghe Arm.

All these sensors are integrated into a RTA console (Real Time Applience) that transmits the data through UTP (Unshielded Twisted Pair) connection to a computer that runs ES3 together with Hypack software, where all this data is integrated and carefully calibrated. As soon as the equipment was installed on the survey boat, calibrated and checked, the survey started and the mapping routing paths of the Ivancea meander can be seen in Figure 3. The Figure 4 is displaying the data acquisition process, where the surveyor can monitor all the aspects of the measurement such as boat direction, soundings cover, the aspect of the profile, the different messages of the system, etc. This facilitates the data collection process to be as accurate as possible. As a result of the completion of the bathymetric data collection campaign, the general picture of the Ivancea meander riverbed aspect is shown in the final matrix (Fig. 5).

Table 1. The flow distribution at the Sf. Gheorghe bifurcation

\begin{tabular}{|l|r|r|r|}
\hline Arm name & Measured Flow (mc/s) & Flow with correction & Distribution (\%) \\
\hline Tulcea & 3,674 & 3,674 & - \\
\hline Sulina & 1,425 & $1,457.5$ & 39.67 \\
\hline Sf. Gheorghe & 2,184 & $2,216.5$ & 60.33 \\
\hline
\end{tabular}

\section{RESULTS AND DISCUSSION}

At first glance, a typical characteristic of meandering morphology is observed on the color palette. The river bed scours occur at a range of scales and settings and are most pronounced at river bends and channel confluences. The depths are surprisingly high 
considering the low hydraulic slope and the proximity $(\sim 10 \mathrm{Km})$ of the mouth of arm into the Black Sea. However, the erosion processes are strong in the upstream part of the meander, where it erodes in the left bank of the island created by the hydraulic regulation, thus generating very high currents and depths $(-24 \mathrm{~m})$. But this is normal and to be expected for such natural processes. Further downstream on the meander, there is a submerged island in the convex part of the meander (close to the right bank) that acts as a barrier, thus protecting the former depths of the main course behind it, and also behaving as a precursor to the visible fairway that almost extends downstream, to the confluence with the main flow of the arm. The average depths are $-12 \mathrm{~m}$, in the upstream area where the erosion is strong in the meander, the depth is $-24 \mathrm{~m}$, the fairway that starts from the middle of the meander towards downstream has an average depth of $-15 \mathrm{~m}$, and downstream, at the confluence, where both discharges are rejoined, there is a deepening of the fairway that reaches up to $-19 \mathrm{~m}$.

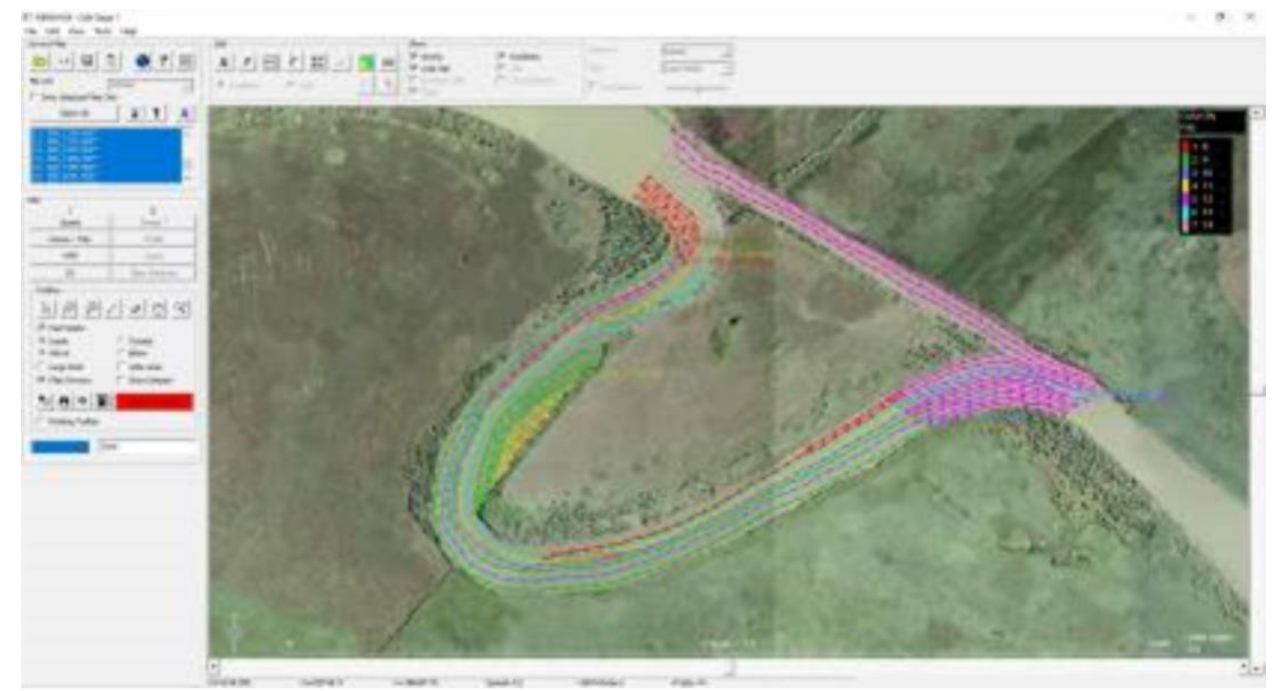

Figure 3. Boat routes for covering the whole survey area

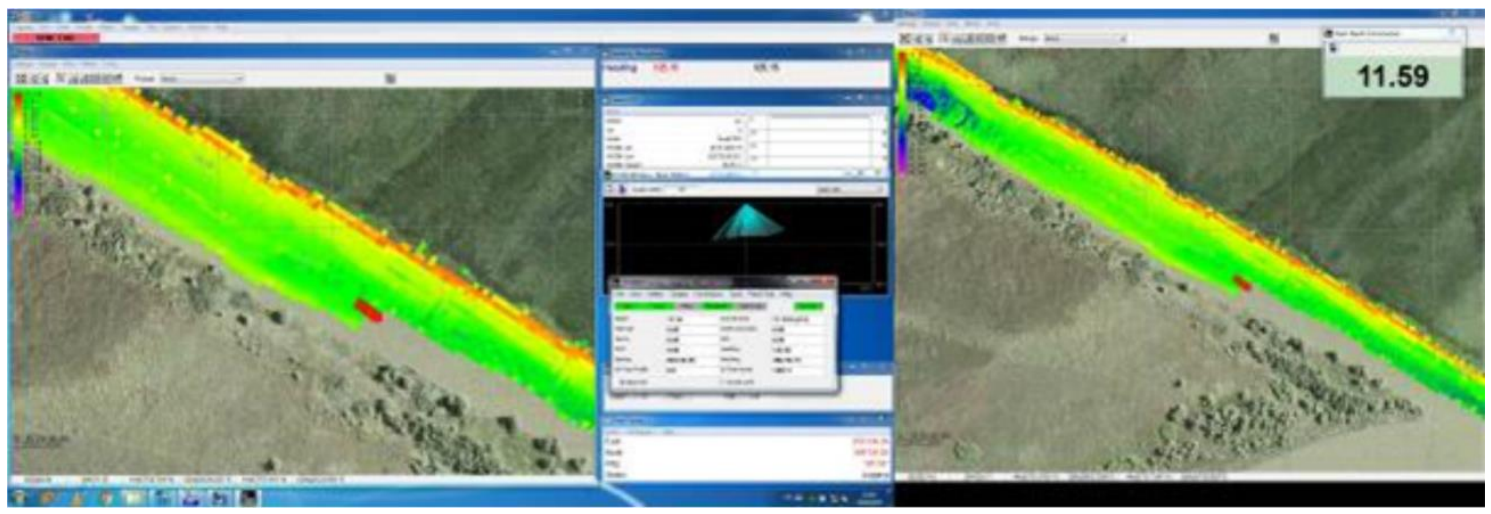

Figure 4. Print screen of the data collection process with the multi-beam interferometer

Data processing is done with in Hypack software package. This is modular software that allows to be used concurrently with other analysis processes. The MBMax module is used to process multibeam bathymetric data, allowing editing of collected points in the field by editing the anomalies, etc. The data can be viewed and edited as color-coded 
wireframe, dots, mesh and variable number of soundings (depending on the computational resources). Some examples can be seen in Figures 6, 7 and 8.

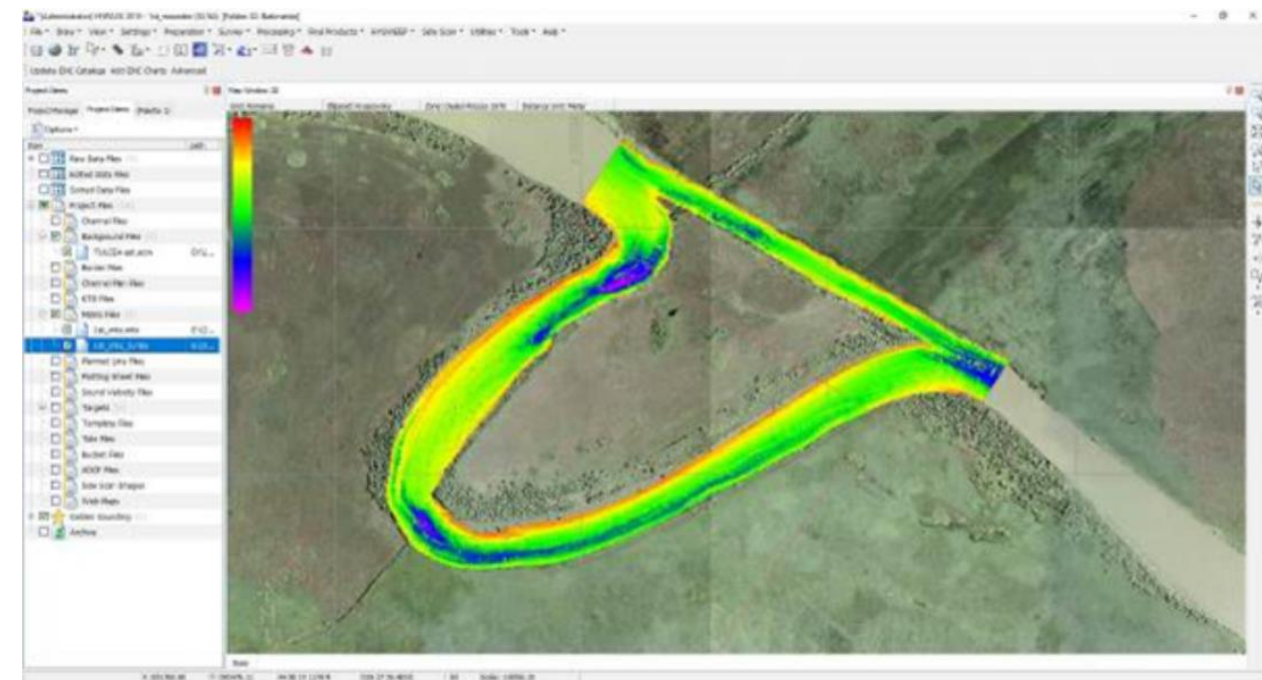

Figure 5. Matrix of raw bathymetric data collection

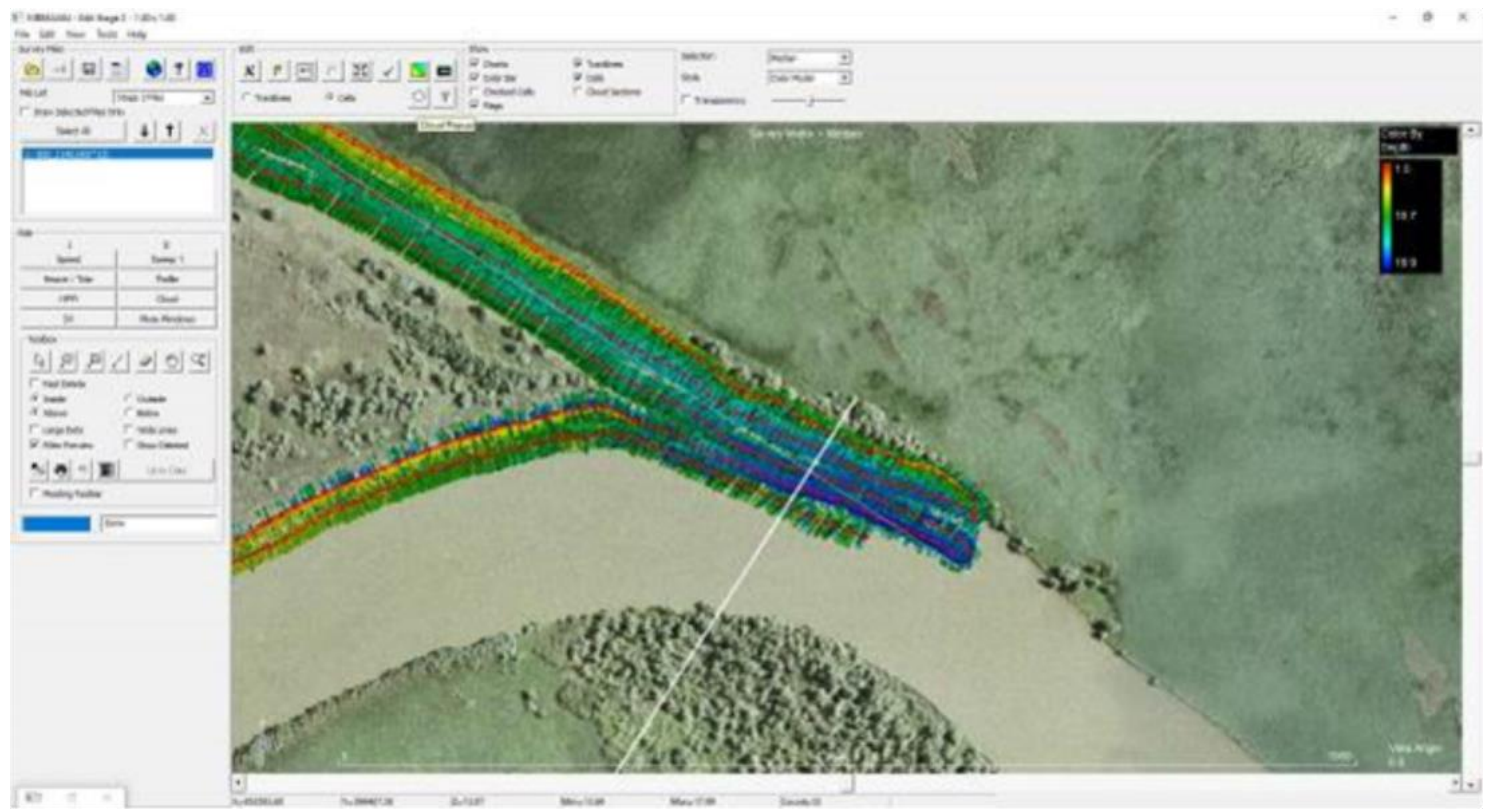

Figure 6. The sample location of the bathymetric data - downstream of the main course confluence with the meander

The anomalies can be observed the in the collected data, namely those lines that rise or fall abruptly. These are referred in the literature as "spikes" and are usual abnormalities in any bathymetric data collection process. These occur due to a misinterpretation of the transducer induced by many variables: boat shocks due to engine speed, high velocity changes in water, suspended particle matter, fish banks, positioning error (changing the horizon of a one or more satellites), loss of TRK communication with the base GPS, etc. These abnormalities can be erased to a limited extent automatically by applying a depth filter and to a large extent manually. The software allows the user to view cloud points in multiple ways so that editing this data is as easy as possible. The data processing is a very meticulous task with trial and error methodologies, and the results are expert judgment 
because in many cases the user needs to interpret data where bathymetric values are missing or are displaying errors.

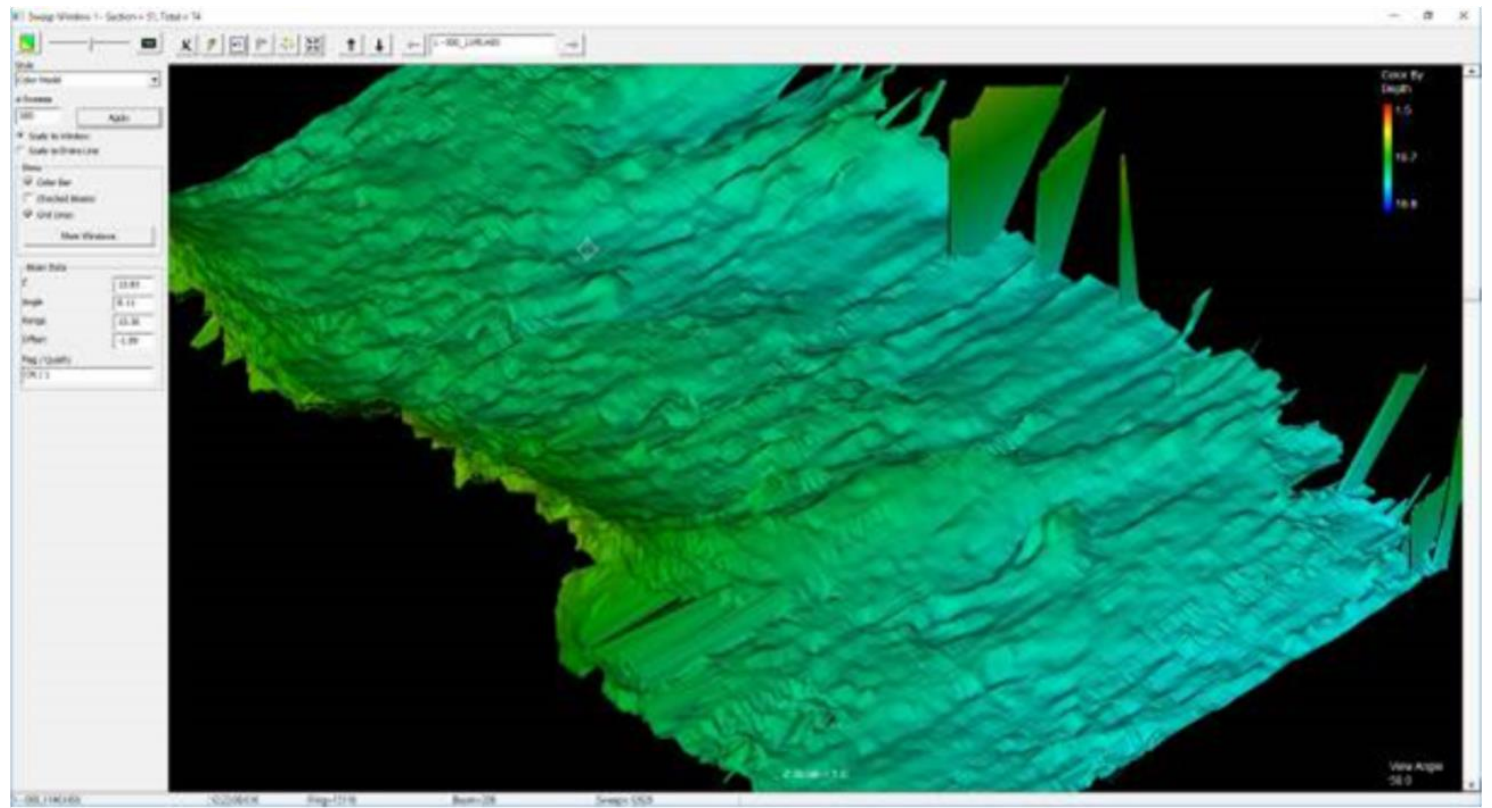

Figure 7. Representing raw data as a mash model

with a gradual colour palette according to the depths in the bathymetric data collection matrix

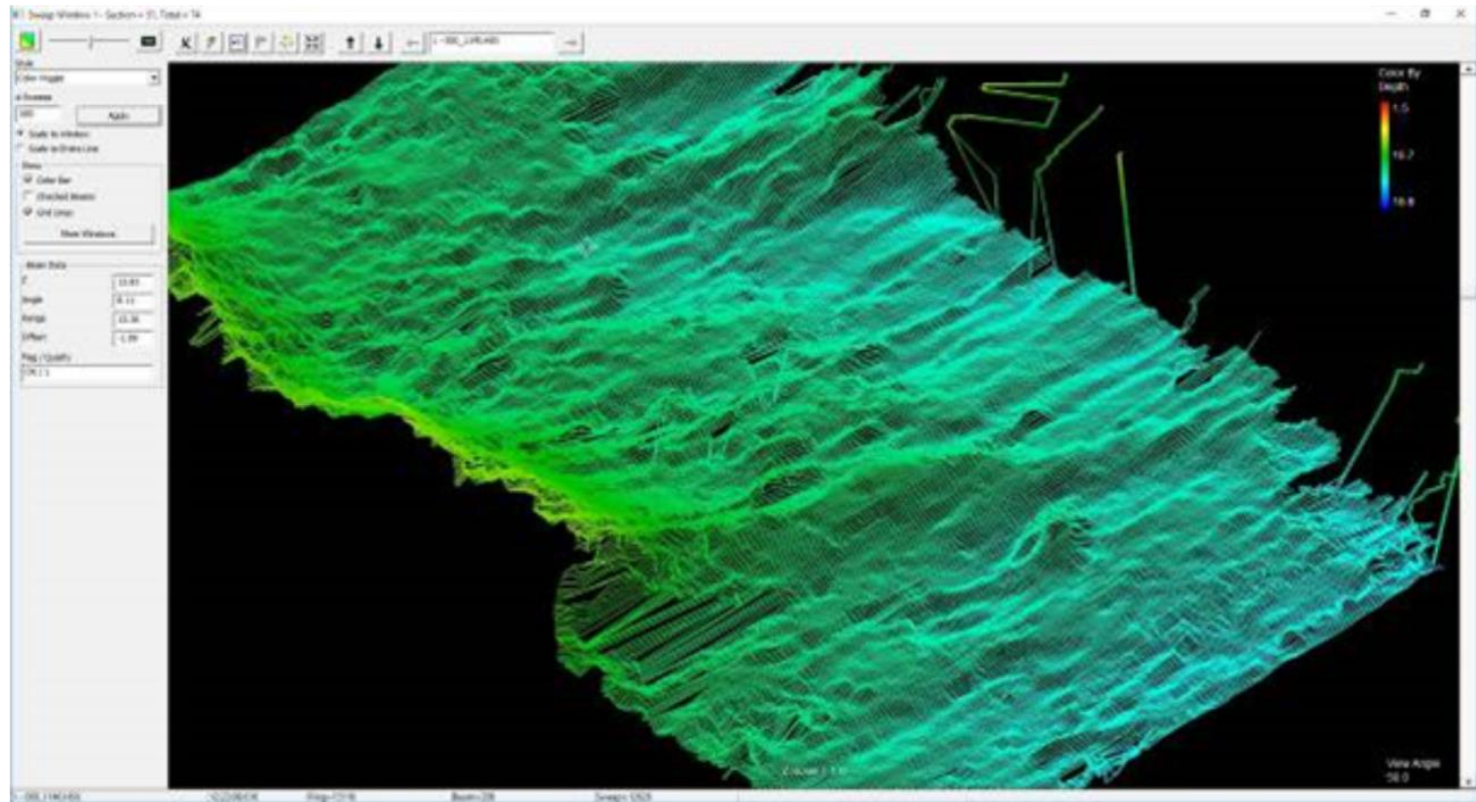

Figure 8. Representing raw data as wireframe soundings

with the gradual colour palette according to depths in the bathymetric data collection matrix

\section{CONCLUSIONS}

The studies conducted by the Institute for Hydraulic Research on the rectification of the Sf. Gheorghe arm have predicted, as it was normal, that the execution of the meanders regularization as well as the diverting channel to the south of the arm will probably lead to an increase of the flow with $4-6.5 \%$ at average flow rates. The researches mainly focused on the knowledge of the drainage system and the sandy river deposits, in the new 
conditions, due to the regularization of the meanders. At the same time, on the changes in the sedimentary balance of the coastal zone and consequently in the evolution of the erosion processes of the beaches under the influence of the flow regime is changes. The hydrological situations in which the measurement campaigns were conducted were quite different from one year to the next. Liquid and solid flow data refers to the situation on the measurement day and any generalization must be taken into account by applying this coefficient. Thus, between 1988 and 1993, the highest liquid flow of the Sf. Gheorghe arm, measured in September 1989, was $1,034 \mathrm{~m}^{3} / \mathrm{s}$. In 1990, also in September, were measured the lowest water levels, flow rates and liquid and solid flows of the Danube in the last 40 years; this year the average liquid flow on Sf. Gheorghe arm was $502 \mathrm{~m}^{3} / \mathrm{s}$. A similar situation occurred in August 1992, when the average liquid flow was $567 \mathrm{~m}^{3} / \mathrm{s}$. In the autumn of 1991 and in August 1993, liquid flows had higher values: $886 \mathrm{~m}^{3} / \mathrm{s}$ and 829 $\mathrm{m}^{3} / \mathrm{s}$.

The liquid flow distribution factors of the Tulcea branch between the Sulina and Sf. Gheorghe arms, under small and average flow rates recorded on the days when the historical measurements were made, are the following: 1993 (average flow): Tulcea M34 $=3,072 \mathrm{~m}^{3} / \mathrm{s}$, Sulina $=0.54 * \mathrm{Q}$ Tulcea, Sf. Gheorghe $=0.46^{*} \mathrm{Q}$ Tulcea; 1992 (low flow): Tulcea M34 = 1,210 $\mathrm{m}^{3} / \mathrm{s}$, Sulina $=0.63 * \mathrm{Q}$ Tulcea; Sf. Gheorghe $=0.37 * \mathrm{Q}$ Tulcea; 1990 (low-medium flow): Q Tulcea M34 $=1,800 \mathrm{~m}^{3} / \mathrm{s}$, Sulina $=0.54 * \mathrm{Q}$ Tulcea, Sf. Gheorghe $=0.46^{*} \mathrm{Q}$ Tulcea. By comparing these distributions with the previous situation, namely: period $1928-1929$ : Sulina $=0.41 * Q$ Tulcea, Sf. Gheorghe $=0.59 * Q$ Tulcea; period 1958 -1960 : Sulina $=0.45^{*} \mathrm{Q}$ Tulcea, Sf. Gheorghe $=0.55^{*} \mathrm{Q}$ Tulcea.

There is a change in the distribution of water between the Tulcea branch and the Sulina and Sf. Gheorghe arms. This change occurred between 1970 and 1980 and is probably due to the constructive additions to the consolidation of the bifurcation point on Sf. Gheorghe, which partly deviates the current to Sulina arm, as well as the natural tendency of silting and advancing towards $\mathrm{N}$ of the right concave bank (southern) of the Tulcea and Sf. Gheorghe arms right at the bifurcation, which determines the direction of a larger part of the flow to the Sulina branch, especially during the periods of small waters. By comparing all this historical data with the recent measurements, it is clearly that the flow has increased on Sf. Gheorghe arm and the distribution is almost the same as prior to the hydraulic implementations on the Sf. Gheorghe arm. This remains to be further investigated within this $\mathrm{PhD}$ thesis. The problem, far from being elucidated, remains a very interesting objective for further research, especially for high liquid flow and flood conditions, these situations being also those that play the most important role in geo- and hydro- dynamic modeling of the area.

\section{REFERENCES}

[1] Romanescu G., Pascal M., Mihu-Pintilie A., Stoleriu C.C., Sandu I. \& Moisii, M. Water Quality Analysis in Wetlands Freshwater: Common Floodplain of Jijia-Prut Rivers, Revista de chimie, Romania, vol. 68(3), pp 553-561, 2017.

[2] Romanescu G. Morpho-hydrographical evolution of the Danube Delta - Aquatic surfaces and inner lands, Ed. PIM, Romania, 2003.

[3] Romanescu G. Complexul lagunar Razim-Sinoie. Studiu morfohidrografic, Ed. Universitatii „Alexandru Ioan Cuza” of Iasi, Romania, 2006. 
[4] Romanescu G. Geoarchaeology of the ancient and medieval Danube Delta: Modeling environmental and historical changes. A review, Quaternary International, vol. 293, pp 231-244, 2013.

[5] Romanescu G. The catchment area of the Milesian colony of Histria, within the Razim-Sinoie lagoon complex (Romania): hydro-geomorphologic, economic and geopolitical implications, Area, UK, vol. 46(3), pp 320-327, 2014.

[6] Romanescu G. Tourist exploitation of archaeological sites in the Danube Delta Biosphere Reserve area (Romania), International Journal of Conservation Science, Romania, vol. 7(3), pp 683-690, 2016.

[7] Romanescu G. \& Cojocaru I. Hydrogeological considerations on the western sector of the Danube Delta - a case study for the Caraorman and Saraturile fluvial-marine levees (with similarities for the Letea levee), Environmental Engineering and Management Journal, Romania, vol. 9(6), pp 795-806, 2010.

[8] Romanescu G. Alluvial Transport Processes and the Impact of Anthropogenic Intervention on the Romanian Littoral of the Danube delta, Ocean \& Coastal Management, vol. 73, pp 31-43, 2013.

[9] Romanescu G. \& Stoleriu C. Anthropogenic interventions and hydrological-risk phenomena in the fluvial-maritime delta of the Danube (Romania), Ocean \& Coastal Management, vol. 102, pp 123-130, 2014.

[10] Adopo K.L., Romanescu G., N'Guessan A.I. \& Stoleriu C. Relations between man and nature and environmental dynamics at the mouth of the Komoé river, Grand-Bassam (Ivory Coast), Carpathian Journal of Earth and Environmental Sciences, Romania, vol. 9(4), pp 137-148, 2014.

[11] Adopo K.L., N'Guessan M.Y., Sandu A.V., Romanescu G. \& Sandu I.G. The spatial distribution and characterization of sediments and the bottom morphology of the hydroelectric lake in Ayamé 2 (Ivory Coast), International Journal of Conservation Science, Romania, vol. 7(2), pp 567-578, 2016.

[12] Allenbach K., Garonna I., Herold C., Monioudi I., Giuliani G., Lehmann A. \& Velegrakis A.F. Black Sea beaches vulnerability to sea level rise, Environmental Science \& Policy, vol. 46, pp 95-109, 2014.

[13] Eilersten R.S. \& Hansen L. Morphology of river bed scours on a delta plain revealed by interferometric sonar, Geomorphology, vol. 94, pp 58-68, 2008.

[14] Feodot I., Project Nr. PN 092604 08, Morpho-fractal analysis of the hydro-morphological dynamics of the Danube Delta's main branches - Complex analysis of the macroforms - the meanders and islands of the Sf. Gheorghe arm, 2015.

[15] Geological Center and Marine Geo-ecology, Scientific research No.2 - The study of the sedimentological and geological complex of the environmental changes in the Danube Delta and the adjacent coastal zone determined by the hydrotechnical regulations on Sf. Gheorghe arm for the identification of protection measures of deltaic and coastal ecosystems, 1995.

[16] Keremedchiev S. \& Valchev N. Morphodynamic analysis of the coastal zone in the area of St. George sub-delta (Danube Delta) and the Sakalin Island (NW Black Sea), Comptes Rendues de l'Academie Bulgare des Sciences, vol. 61(8), pp 1037-1046, 2008.

[17] Matenco L., Munteanu I., Borgh M., Stanica A., Tilita M., Lericolais G., Dinu C. \& Oaie G. The interplay between tectonics, sediment dynamics and gatways evolution in the Danube system from the Pannonian Basin to the western Black sea, Science of the Total Environment, vol. 543, pp 807-827, 2015.

[18] Provansal M., Vella C. \& Sabatier F. Sedimentary imputs and mobility of deltaic coasts during the Holocene, Oceanis, France, vol. 29, pp 209-238, 2006. 
[19] Vespremeanu-Stroe A., Zăinescu F., Preoteasa L., Tătui F., Rotaru S., Morhange C., Stoica M., Hanganu F., Timar-Gabor A., Cârdan I. \& Piotrowska N. Holocene evolution of the Danube delta: an integral reconstuction and an revised chronology, Marine Geology, vol. 388, pp 38-61, 2017.

[20] Mierla M., Romanescu G., Nichersu I. \& Grigoras I. Hydrological risk map for the Danube delta - a case study of floods within the fluvial delta, IEEE Journal of Selected Topics in Applied Earth Observations and Remote Sensing, vol. 8, pp 98-104, 2015.

[21] Radevski I. \& Gorin S. Floodplain analysis for different return periods of river Vardar in Tikvesh valley (Republic of Macedonia), Carpathian Journal of Earth and Environmental Sciences, Romania, vol. 12, pp 179-187, 2017.

[22] Romanescu G. Morphology and Dynamics of the Danube Delta Littoral between the Sulina and Sfântu Gheorghe River Mouths (Romania), Revista Pontica, Romania, vol. 43, pp 515-531, 2010.

[23] Romanescu G., Sandu I., Stoleriu C. \& Sandu I.G. Water Resources in Romania and Their Quality in the Main Lacustrine Basins, Revista de Chimie (Bucharest), Romania, vol. 65(3), pp 344-349, 2014.

[24] Romanescu G. Geomorfologie litorala, Ed. Transversal, Romania, 2015.

[25] Romanescu G., Bounegru O., Stoleriu C., Mihu-Pintilie A., Nicu C., Enea A. \& Stan O. The ancient legendary island of PEUCE - myth or reality? Journal of Arechaeological Science, vol. 53, pp 521-535, 2015.

[26] Romanescu G. \& Stoleriu C. Exceptional floods in the Prut basin, Romania, in the context of heavy rains in the summer of 2010, Natural Hazards and Earth System Sciences, vol. 17, pp 381-396, 2017.

[27] Romanescu G., Cimpianu C.I., Mihu-Pintilie A. \& Stoleriu C.C. Historic flood events in NE Romania (post-1990), Journal of Maps, vol. 13(2), pp 787-798, 2017.

[28] Romanescu G., Mihu-Pintilie A., Stoleriu C.C., Carboni D., Paveluc L.E. \& Cimpianu C.I. A Comparative Analysis of Exceptional Flood Events in the Context of Heavy Rains in the Summer of 2010: Siret Basin (NE Romania) Case Study, Water, vol. 10(2), 216, pp 1-17, 2018.

[29] Romanescu G., Chalov S., Stoleriu C.C., Mihu-Pintilie A., Angileri S.E., Kuznetsova Y., Cama M. \& Maerker M. Geomorphologic map of the $1^{\text {st }}$ Mutnaya River, Southeastern Kamchatka, Russia, Journal of Mountain Science, vol. 14(2), pp 2373-2390, 2017.

[30] Romanescu G., The tourist potential of coasts and deltas. A look at the romanian coastal areas, Parthenon Verlag, Geist \& Wissenschaft, Kaiserslautern und Mehlingen, 2012. 